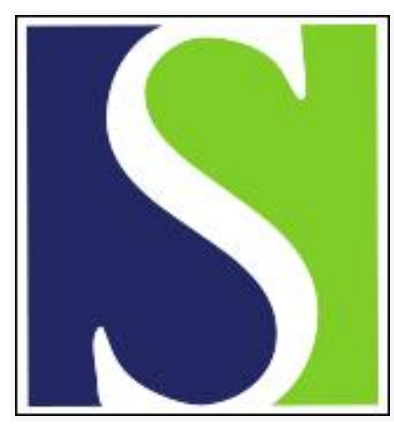

Scand J Work Environ Health 1990;16(3):175-181

https://doi.org/10.5271/sjweh.1799

Issue date: 01 Jun 1990

Respiratory symptoms and pulmonary function of workers exposed to cork dust, toluene diisocyanate and conidia.

by Alegre J, Morell F, Cobo E

Affiliation: Department of Pneumology, Hospital General Vali d'Hebron, Barcelona, Spain.

This article in PubMed: www.ncbi.nlm.nih.gov/pubmed/2166333

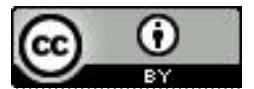




\title{
Respiratory symptoms and pulmonary function of workers exposed to cork dust, toluene diisocyanate and conidia
}

\author{
by Josep Alegre, MD, ${ }^{1}$ Ferran Morell, MD, ${ }^{1}$ Eric Cobo, $\mathrm{MD}^{2}$
}

\begin{abstract}
ALEGRE J, MORELL F, COBO E. Respiratory symptoms and pulmonary function of workers exposed to cork dust, toluene diisocyanate and conidia. Scand J Work Environ Health 1990;16:175-81. A crosssectional study on suberosis was conducted to determine the prevalence of respiratory symptoms and the level of pulmonary function, and their relationships within job categories of exposure to cork dust, toluene diisocyanate (TDI) resin bonding and conidia, among cork workers. Exposure-response relationships, with confounders taken into account, showed specific associations between cork dust and chronic bronchitis, TDI and asthma, and conidia and symptoms of hypersensitivity pneumonitis. Workers exposed to these risk factors had reduced mean spirometric values. A significant correlation between a decrease in pulmonary function and length of exposure was found for the workers exposed to cork dust. These results strongly suggest that suberosis, as hitherto described, might in fact be comprised of three different diseases with different etiologic risk factors, ie, respiratory hypersensitivity from exposure to conidia, asthma from exposure to TDI, and chronic obstructive pulmonary disease from exposure cork dust.
\end{abstract}

Key terms: chronic obstructive pulmonary disease, cross-sectional study, exposure-response relations, respiratory hypersensitivity, suberosis.

Suberosis, a respiratory disease of cork workers, was first described by Portuguese authors (1) as hypersensitivity pneumonitis, and the pathology included sarcoid-type granulomas with cork inclusions in the pulmonary interstitium and bronchial wall (2). The etiology was attributed to cork dust and Penicillium frequentans $(3,4)$, although inhalatory provocation tests were only positive to $P$ frequentans. Nevertheless, the clinical presentation of suberosis was polymorphous, since patients complained of symptoms typical of either hypersensitivity pneumonitis or asthma and even a form of bronchitis (2).

Toluene diisocyanate (TDI) is used in the cork industry for the processing of cork agglomerates. Despite the known risk of asthma with exposure to TDI $(5-11)$, its etiologic role in suberosis has not been considered until now. Furthermore, occupational exposure to cork dust in grinding and polishing has not been studied as a possible risk factor for other respiratory diseases.

Taking into account the aforementioned risk factors, we suggest that the varied symptomatology of suberosis may point to several different diseases, each with its own determining factor.

Since few attempts to detect suberosis have been made in Spain, the world's second largest producer of

I Department of Pneumology, Hospital General Vall d'Hebrón, Barcelona, Spain.

2 Department of Public Health, University of Barcelona, Escola de Alta Direcció i Administració (EADA), Barcelona, Spain.

Reprints requests to: Dr J Alegre, Department of Pneumology, Hospital General Vall d'Hebrón, Paseo Vall d'Hebrón s/n, 08035 Barcelona, Spain. cork, this study was conducted to determine the prevalence of respiratory symptoms and the level of pulmonary function of Spanish cork workers and to analyze relations between these two factors and occupational exposure in the cork industry.

\section{Subjects and methods}

Forty-two small factories involved in various stages of cork processing were surveyed in 1984. From a total of 488 workers the final study group consisted of $\mathbf{4 4 2}$. The 46 nonrespondents included 36 who refused to participate and 10 who were absent for health reasons, although none suffered from respiratory ailments.

\section{Cork manufacturing process}

Processes involved in the manufacture of cork depend on the end product to be obtained. "Natural" stoppers (wine-bottle corks) are made from bark which is boiled, stored under dark humid conditions until moldy, sliced, punched, and polished; cork agglomerates for use as parquet flooring, wallpaper, wall coverings, bulletin boards, shoe soles, life belts, champagne corks, etc, are manufactured from ground bark that is blended with TDI resin bonding; blocks and panels for industrial soundproofing are obtained from ground bark which is agglomerated under pressure and heating.

\section{Risk factors}

The criteria for exposure to the respiratory risk factors present in the different stages of cork manufac- 
turing were established according to those of Gamble \& Spirtas (12). Technicians from the Gerona Department of Health and Work Safety surveyed 42 factories to study cork processing and the respiratory risk factors involved.

The job-exposure categories were defined as follows according to the qualitative direct exposure in the various job activities: (i) exposure to conidia: working or having worked as a slicer or puncher of moldy cork; (ii) exposure to cork dust: having worked for a minimum of two years as a grinder or polisher of cork; (iii) exposure to TDI: working or having worked as a blender of cork sawdust and TDI resin bonding.

The respective nonexposure categories were those of "not working or not having worked" in the aforementioned job activities.

\section{Personal interview}

The following three questionnaires were administered by trained interviewers: (i) a modified version of the standard ATS-DLD-1978 respiratory and smoking questionnaire (13); (ii) an exposure and occupational history questionnaire based on the report of the American College of Chest Diseases of San Diego (14); (iii) a questionnaire to assess hypersensitivity pneumonitis, adapted from the criteria of Grant et al (15) for the study of farmer's lung.

\section{Respiratory diseases}

The respiratory illnesses studied were defined as follows: (i) chronic bronchitis: cough and phlegm on most days for at least three months a year for two or more consecutive years (16); (ii) asthma: history of acute, reversible attacks of dyspnea or shortness of breath with wheezing $(17,18)$; (iii) symptoms hypersensitivity pneumonitis: more than two bouts of occupationally related coughing, chest tightness, or dyspnea without wheezing with or without fever and the cessation of symptoms during exposure-free periods or once exposure has ended.

\section{Pulmonary function}

Spirometry was performed with a Vitalograph ${ }^{(\beta)}$ spirometer (7 l) in a room with a constant temperature according to the instructions of the American Thoracic Society (19) for both the spirometric test and the calibration. Calibrations of the spirometer with a explosive decompressor (20) showed reproducibility within the standards of the American Thoracic Society. The 18 subjects who failed to meet the spirometric requirements were excluded.

\section{Precipitin test}

Precipitating antibodies were detected by counter electrophoresis. $P$ frequentans extracts at concentrations of 10 and $5 \mathrm{mg} / \mathrm{ml}$ were used (Ifidesa Aristegui Laboratories, Bilbao, Spain).

\section{Confounding factors}

Potential confounders were sex, age, smoking, other exposures with respiratory risk, history of respiratory diseases, atopy (prick-test response to common allergens considered positive when papules measured $3 \mathrm{~mm}$ or more in diameter when compared with papules obtained with isotonic saline).

Two age categories ( $<40$ years or $\geq 40$ years) were used in the respiratory symptoms analysis, whereas age was used as a continuous variable in the pulmonary function analysis.

The health effects of smoking (packs/year and cigarettes/day) were assessed. In the multivariate analyses the smoking categories were current smokers (more than one cigarette per day in a year), nonsmokers, and ex-smokers (stopped smoking at least three months before).

\section{Analysis}

The main objective of the study was to analyze for exposure-response relationships, and the strategies proposed by Weiss \& Liff (21) for studying multifactorial diseases with a cross-sectional design were applied (22). To avoid the confounding effect of multiple exposure, more common for the mobile workers (those currently employed in more than one job activity), all the workers were included in all the job categories to which they had been exposed. When submitted to analysis, the workers in each job category were compared with the rest of the study population to limit bias caused by multifactorial disease.

The data analysis was carried out with the statistical package for the social sciences and the biomedical package. Potential risk factors, relevant for at least $5 \%$ of the study group, formed part of a first bivariate study with respiratory symptoms. The exposureresponse associations underwent multivariate analyses which included the confounders. Thus we applied a loglinear analysis (23) for the study of relations between chronic bronchitis, asthma, and symptoms of hypersensitivity with the suspected risk factors. Coefficients of partial association (24) and the estimated adjusted odds ratio (OR) in loglinear models which included interfactorial associations were used for the significance assessment.

The evaluation of pulmonary function with an analysis of covariance (ANCOVA) and a multiple regression focused on determining the dependence of the spirometric parameters [forced vital capacity (FVC), forced expiratory volume in $1 \mathrm{~s}\left(\mathrm{FEV}_{1.0}\right)$, and forced expiratory flow rate at $25-75 \%$ of the forced vital capacity $\left.\left(\mathrm{FEF}_{25-75}\right)\right]$ on the risk factors under study, after adjustment for age, sex, height, weight, smoking, and the job-exposure categories. 


\section{Results}

The physical characteristics and smoking categories of the workers are shown in table 1 , and their occupational activities are presented in table 2 . There was a clear predominance of men in the activities involving exposure to the risk factors (slicing, polishing, and blending). It is important to note the prevalence (14\%) of mobile workers, the relatively short time of employment in the cork industry, and the high prevalence of male smokers.
Newcomers (one year's employment or less) predominated in the job categories in close contact with the proposed risk factors. There were no significant differences in the smoking habits of the workers in the different exposure categories (table 3 ).

The prevalence of cough, phlegm, chronic bronchitis, daily wheezing, attacks of asthma, and symptoms of hypersensitivity pneumonitis are shown in table 4 according to the smoking and exposure categories. It can be seen that the workers exposed to cork dust

Table 1. Age, height, years worked, and smoking categories of the workers.

\begin{tabular}{|c|c|c|c|c|c|c|c|c|c|c|}
\hline & \multirow[b]{2}{*}{$\mathrm{N}$} & \multicolumn{2}{|c|}{ Age (years) } & \multicolumn{2}{|c|}{ Height (cm) } & \multicolumn{2}{|c|}{ Years worked } & \multicolumn{3}{|c|}{ Smoking category } \\
\hline & & Mean & SD & Mean & SD & Mean & SD & $\begin{array}{l}\text { Non- } \\
\text { smokers } \\
(\%)\end{array}$ & $\begin{array}{c}\text { Current } \\
\text { smokers } \\
(\%)\end{array}$ & $\begin{array}{c}\text { Ex- } \\
\text { smokers } \\
(\%)\end{array}$ \\
\hline $\begin{array}{l}\text { Men } \\
\text { Women }\end{array}$ & $\begin{array}{l}247 \\
195\end{array}$ & $\begin{array}{l}43 \\
38\end{array}$ & $\begin{array}{l}13 \\
14\end{array}$ & $\begin{array}{l}168 \\
157\end{array}$ & $\begin{array}{l}6 \\
7\end{array}$ & $\begin{array}{l}14 \\
12\end{array}$ & $\begin{array}{l}12 \\
11\end{array}$ & $\begin{array}{l}21 \\
77\end{array}$ & $\begin{array}{l}57 \\
20\end{array}$ & $\begin{array}{r}22 \\
3\end{array}$ \\
\hline Men + women & 442 & 41 & 14 & 163 & 9 & 13 & 11 & 46 & 40 & 14 \\
\hline
\end{tabular}

Table 2. Distribution of the workers by current job activity.

\begin{tabular}{|c|c|c|c|c|c|c|c|c|c|}
\hline & $\mathrm{N}$ & $\begin{array}{c}\text { Slicing } \\
(\%)\end{array}$ & $\underset{(\%)}{\text { Grinding }}$ & $\begin{array}{c}\text { Selectors } \\
(\%)\end{array}$ & $\begin{array}{c}\text { Ware- } \\
\text { house } \\
(\%)\end{array}$ & $\begin{array}{c}\text { Office } \\
(\%)\end{array}$ & $\begin{array}{c}\text { Supervisor } \\
(\%)\end{array}$ & $\begin{array}{c}\text { Blender } \\
(\%)\end{array}$ & $\begin{array}{c}\text { Mobile } \\
\text { worker } \\
(\%)\end{array}$ \\
\hline $\begin{array}{l}\text { Men } \\
\text { Women }\end{array}$ & $\begin{array}{l}247 \\
195\end{array}$ & $\begin{array}{l}22 \\
10\end{array}$ & $\begin{array}{r}11 \\
2\end{array}$ & $\begin{array}{r}4 \\
72\end{array}$ & $\begin{array}{l}7 \\
4\end{array}$ & $\begin{array}{l}8 \\
5\end{array}$ & $\frac{10}{-}$ & $\begin{array}{r}16 \\
3\end{array}$ & $\begin{array}{r}22 \\
4\end{array}$ \\
\hline Men + women & 442 & 16 & 7 & 34 & 6 & 7 & 6 & 10 & 14 \\
\hline
\end{tabular}

Table 3. Smoking (frequency, chi-squared not significant) and worker turnover by exposure to conidia, toluene diisocyanate (TDI), and cork dust. ( $95 \% \mathrm{Cl}=95 \%$ confidence interval)

\begin{tabular}{lccccrrr}
\hline & & \multicolumn{3}{c}{ Smoking category } & & \multicolumn{2}{c}{ Worker turnover } \\
\cline { 3 - 6 } Exposure & $N$ & $\begin{array}{c}\text { Non- } \\
\text { smokers } \\
(\%)\end{array}$ & $\begin{array}{c}\text { Current } \\
\text { smokers } \\
(\%)\end{array}$ & $\begin{array}{c}\text { Ex- } \\
\text { smokers } \\
(\%)\end{array}$ & & $\%$ & $95 \% \mathrm{Cl}$ \\
\hline Overall & 442 & 46 & 40 & 14 & 9 & $6.3-11.7$ \\
Conidia & 100 & 30 & 51 & 19 & 16 & $8.8-23.2$ \\
TDl & 50 & 20 & 60 & 20 & 28 & $15.6-40.4$ \\
Cork dust & 52 & 31 & 54 & 15 & 12 & $3.2-20.8$ \\
\hline
\end{tabular}

Table 4. Prevalence of cough, phlegm, chronic bronchitis, wheezing, asthma, and symptoms of hypersensitivity pneumonitis by job exposure to conidia, toluene diisocyanate (TDI), and cork dust and by smoking category.

\begin{tabular}{|c|c|c|c|c|c|c|c|}
\hline & $\mathrm{N}$ & $\begin{array}{c}\text { Cough } \\
(\%)\end{array}$ & $\begin{array}{c}\text { Phlegm } \\
(\%)\end{array}$ & $\begin{array}{c}\text { Chronic } \\
\text { bronchitis } \\
(\%)\end{array}$ & $\begin{array}{c}\text { Wheeze } \\
(\%)\end{array}$ & $\begin{array}{c}\text { Asthma } \\
(\%)\end{array}$ & $\begin{array}{c}\text { Symptoms of } \\
\text { hypersensitivity } \\
\text { pneumonitis } \\
(\%)\end{array}$ \\
\hline \multicolumn{8}{|c|}{ Job-exposure category } \\
\hline $\begin{array}{l}\text { Cork dust } \\
\text { TDI } \\
\text { Conidia }\end{array}$ & $\begin{array}{r}52 \\
50 \\
100\end{array}$ & $\begin{array}{l}48 \\
44 \\
37\end{array}$ & $\begin{array}{l}52 \\
46 \\
33\end{array}$ & $\begin{array}{l}38 \\
34 \\
22\end{array}$ & $\begin{array}{r}10 \\
22 \\
3\end{array}$ & $\begin{array}{r}2 \\
14 \\
3\end{array}$ & $\begin{array}{r}8 \\
6 \\
17\end{array}$ \\
\hline \multicolumn{8}{|c|}{ Smoking category } \\
\hline $\begin{array}{l}\text { Nonsmoker } \\
\text { Smoker } \\
\text { Ex-smoker }\end{array}$ & $\begin{array}{r}203 \\
177 \\
62\end{array}$ & $\begin{array}{l}18 \\
50 \\
29\end{array}$ & $\begin{array}{l}16 \\
43 \\
38\end{array}$ & $\begin{array}{l}10 \\
31 \\
21\end{array}$ & $\begin{array}{r}3 \\
10 \\
7\end{array}$ & $\begin{array}{l}8 \\
3 \\
8\end{array}$ & $\begin{array}{r}8 \\
8 \\
16\end{array}$ \\
\hline Total & 442 & 32 & 30 & 20 & 6 & 6 & 9 \\
\hline
\end{tabular}


(polishers and grinders) had the highest rate of chronic bronchitis $(38 \%)$, even higher than that of current smokers (31 \%). Similarly, those exposed to TDI (blenders) had the highest prevalence of wheezing $(22 \%)$ and attacks of asthma (14\%). Furthermore, this table shows that those workers exposed to conidia (slicers and punchers of moldy cork) suffered the most from symptoms of hypersensitivity pneumonitis $(17 \%)$.

The overall prevalence of precipitin positive to $P$ frequentans was $13 \%$. Twenty-one percent of the workers exposed to moldy cork had positive precipitin $(\mathrm{P}<0.05)$. There was no significant relation between symptoms of hypersensitivity pneumonitis and serum precipitins, despite the fact that the subjects with these symptoms had the highest prevalence of positive precipitin $(22 \%)$.

To ascertain the role of the confounding factors, primary bivariate analyses were carried out between the confounders and the exposure categories and the respiratory illnesses, respectively. These analyses showed that smoking and sex could cause bias in the study of chronic bronchitis. There was no association between atopy and the exposure categories and the respiratory symptoms.

\section{Chronic bronchitis and exposure to cork dust}

The relation between chronic bronchitis and exposure to cork dust was tested in a multivariate loglinear analysis with adjustment for age and smoking. Owing to the small number of women exposed to cork dust, this analysis was restricted to the men.

The coefficients of partial association were statistically significant between chronic bronchitis and exposure to cork dust $(P=0.022)$ and between chronic bronchitis and age $(P=0.047)$. Higher interaction among these three factors was similarly significant $(P=0.027)$. Thus the relationship between cork exposure and chronic bronchitis had a different intensity in the two age groups.

The adjusted odds ratio for chronic bronchitis among the workers exposed to cork dust was 3.44 [ $95 \%$ confidence interval $(95 \% \mathrm{CI}) 1.48-7.95$ ]. This risk was increased fivefold among the exposed subjects under 40 years of age.

\section{Asthma and exposure to TDI}

To ascertain whether the greater proportion of asthmatics among the workers exposed to TDI was related to the TDI exposure, a loglinear analysis was made for attacks of asthma, exposure to TDI, sex, age, and exposure to conidia. The association between asthma and exposure to TDI was significant $(P=0.01)$. The adjusted odds ratio for asthma among the TDI-exposed workers was $3.22(95 \% \mathrm{CI} 2.87-3.61)$.

\section{Symptoms of hypersensitivity and exposure to conidia}

To test the association found between symptoms of hypersensitivity pneumonitis and exposure to conidia, an analysis was performed with adjustments for exposure to TDI, sex, and age. The results confirmed a significant relation between symptoms of hypersensitivity pneumonitis and exposure to conidia $(\mathrm{P}=$ $0.0007)$ and age $(P=0.008)$. The adjusted odds ratio for symptoms of hypersensitivity among the workers exposed to conidia was 3.23 (95\% CI $1.25-8.33$ ).

\section{Pulmonary function analyses}

The effects of the qualitative exposure to the risk factors on the workers' spirometric values were analyzed by ANCOVA. The analysis, summarized in table 5, showed that the exposed subjects had adjusted mean values lower than the overall means. However, only the differences in the $\mathrm{FEV}_{1.0}$, as adjusted for exposure-nonexposure with respect to smoking and exposure to conidia, and the differences in the $\mathrm{FEF}_{25-75}$, as adjusted for exposure-nonexposure with respect to smoking and exposure to conidia and cork dust, were significant $(\mathrm{P}<0.05)$.

The effects of the duration of exposure to the risk factors on pulmonary function were examined with a multiple regression which tested the relation between each spirometric parameter and the exposure categories, with adjustments for the covariants and smoking. These analyses found only ventilatory impairment with exposure to cork dust and showed a significant correlation between the length of exposure and the adjusted FVC, $\mathrm{FEV}_{1.0}$, and $\mathrm{FEF}_{25-75}$ means of the workers exposed to cork dust. The adjusted coefficients, which measured the variation of the spirometric parameters in milliliters per year of exposure, are shown in table 6. Smoking had an airflow limitation effect, and current smokers had a higher decrease in $\mathrm{FEV}_{1.0}$ and $\mathrm{FEF}_{25-75}$ after adjustments for the covariants and exposure categories (table 5).

\section{Discussion}

The exposure-response associations between chronic bronchitis and cork dust, asthma and TDI, symptoms of hypersensitivity pneumonitis and conidia, and airflow limitation and exposure to cork dust were the most notable features of this study, which provides additional information on suberosis.

The paucity of information on suberosis in Spain led to the choice of a cross-sectional design for the study, mainly as an initial approach to the problem.

There are three main respiratory risk factors involved in the cork manufacturing process: cork dust in grinding and polishing, conidia in the slicing and punching of moldy cork, and TDI resin bonding in the 
blending of cork. Exposure categories, which permitted internal comparison, were established on the basis of the evidence of direct exposure to these risk factors in certain job activities.

Workers' previous illnesses and their occupational profiles were taken into account principally with the objective of avoiding the sources of bias caused by high worker turnover and the healthy worker effect which may confound health assessment $(25-27)$.

The study of prevalences (table 4) suggested exposure-response relationships which were later confirmed in a multivariate analysis. These analyses were always adjusted for sex and smoking.

The first loglinear analysis showed an association between chronic bronchitis and exposure to cork dust, with an odds ratio of 3.44 (95\% CI 1.48-7.95). However, the fivefold increase in the odds ratio of the lower age group of exposed workers could have been due in part to a cessation of exposure and a reduction in smoking in the older age group. This conclusion would be comprehensible if we accept the reversibility of chronic bronchitis symptoms $(28-30)$. These results support the evidence for industrial bronchitis (31-33) and are coherent with the findings of other studies on exposure to organic dusts such as those of cotton or grain (35-37).

The second loglinear analysis further confirmed the association between asthma and exposure to TDI resin bonding. Enarson et al (18) stated that attacks of dyspnea or shortness of breath with wheezing correlate well with bronchial hyperreactivity and appear useful in epidemiologic research. This is the first time that the aforementioned risk factor has been assessed as a possible producer of asthma in the cork industry. Three arguments in favor of this association were found: (i) the association of asthma only with exposure to TDI (specificity); (ii) the strength of the association (OR 3.22, $95 \%$ CI 2.87-3.61); and (iii) coherence with previous studies on isocyanates $(7-9,38-40)$. We believe this finding contributes to the understanding of suberosis, since exposure to cork dust or conidia was not significantly associated with asthma in this study.

The relationship between symptoms of hypersensitivity pneumonitis and exposure to conidia was also

Table 5. Analysis of covariance: adjusted difference with respect to the grand mean in forced expiration (ml) in the study popu-

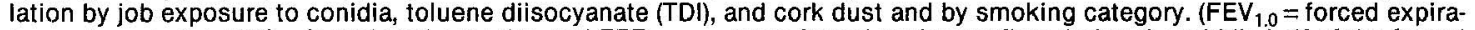
tory volume in $1 \mathrm{~s}, \mathrm{FVC}=$ forced vital capacity, and $\mathrm{FEF}_{25-75}=$ mean forced expiratory flow during the middle half of the forced vital capacity)

\begin{tabular}{|c|c|c|c|c|}
\hline & $N$ & $\mathrm{FEV}_{1.0}$ & FVC & $\mathrm{FEF}_{25-75}$ \\
\hline \multicolumn{5}{|c|}{ Job exposure category } \\
\hline \multicolumn{5}{|c|}{ TDI } \\
\hline $\begin{array}{l}\text { Yes } \\
\text { No }\end{array}$ & $\begin{array}{r}49 \\
375\end{array}$ & $\begin{array}{r}-65 \\
+9\end{array}$ & $\begin{array}{r}-51 \\
+7\end{array}$ & $\begin{array}{r}-10 \\
+1\end{array}$ \\
\hline \multicolumn{5}{|l|}{ Conidia } \\
\hline $\begin{array}{l}\text { Yes } \\
\text { No }\end{array}$ & $\begin{array}{r}96 \\
328\end{array}$ & $\begin{array}{r}-108 \\
+32\end{array}$ & $\begin{array}{l}-87 \\
+25\end{array}$ & $\begin{array}{r}-177 \\
+52\end{array}$ \\
\hline \multicolumn{5}{|l|}{ Cork dust } \\
\hline $\begin{array}{l}\text { Yes } \\
\text { No }\end{array}$ & $\begin{array}{r}50 \\
374\end{array}$ & $\begin{array}{l}-78 \\
+10\end{array}$ & $\begin{array}{r}-21 \\
+3\end{array}$ & $\begin{array}{r}-226 \\
+30\end{array}$ \\
\hline \multicolumn{5}{|c|}{ Smoking category } \\
\hline Nonsmoker & 195 & +52 & +14 & +175 \\
\hline Smoker & 170 & -72 & -50 & -170 \\
\hline Ex-smoker & 59 & +35 & +98 & -90 \\
\hline Total & 424 & 2.957 & 3.666 & 2.945 \\
\hline
\end{tabular}

a Adjusted for age, height, sex, smoking, weight, and job exposure.

Table 6. Multiple regression: regression $(\beta)$ and determination coefficients $\left(R^{2}\right)$ of the spirometric parameters (dependent variable) with years of job exposure to conidia, toluene diisocyanate, or cork dust (independent variable) after adjustment for age, height, sex, smoking, and weight. ( $F E V_{1.0}=$ forced expiratory volume in $1 \mathrm{~s}, F V C=$ forced vital capacity, and $F E F_{25}-75=m^{2}$ ean forced expiratory flow during the middle half of the forced vital capacity)

\begin{tabular}{|c|c|c|c|c|c|c|c|}
\hline \multirow{2}{*}{ Exposure } & \multirow{2}{*}{$N$} & \multicolumn{2}{|c|}{ FVC } & \multicolumn{2}{|c|}{ FEV $_{1.0}$} & \multicolumn{2}{|c|}{$\mathrm{FEF}_{25-75}$} \\
\hline & & $\beta$ & $\mathrm{R}^{2}$ & $\beta$ & $\mathbf{R}^{2}$ & $\beta$ & $\mathrm{R}^{2}$ \\
\hline $\begin{array}{l}\text { Cork dust } \\
\text { Conidia } \\
\text { TDI } \\
\text { Overall }\end{array}$ & $\begin{array}{r}51 \\
97 \\
49 \\
427\end{array}$ & $\begin{array}{r}-34.4 \\
5.8 \\
0.9 \\
-0.91\end{array}$ & $\begin{array}{c}-0.13^{\star} \\
0.00 \\
0.00 \\
0.00\end{array}$ & $\begin{array}{r}-28.5 \\
4.3 \\
16.4 \\
0.4\end{array}$ & $\begin{array}{c}-0.13^{\star} \\
0.00 \\
0.02 \\
0.00\end{array}$ & $\begin{array}{r}-40.6 \\
1.1 \\
42.9 \\
0.4\end{array}$ & $\begin{array}{c}-0.10^{\star} \\
0.00 \\
0.04 \\
0.00\end{array}$ \\
\hline
\end{tabular}

- $\mathrm{P}<0.01$. 
confirmed by the third loglinear analysis. Those exposed to conidia ran a three times greater risk of symptoms of hypersensitivity pneumonitis. This evidence corroborates the work of Portuguese authors $(1-3)$ who found that the inhalation of $P$ frequentans reproduced symptoms of suberosis and that exposure to conidia implies a risk of hypersensitivity pneumonitis $(41,42)$. Those workers with symptoms of hypersensitivity pneumonitis and fever, the latter persistent with exposure to conidia, also had precipitins to $P$ frequentans and restrictive ventilatory impairment, which ruled out the organic dust toxic syndrome (43).

The $95 \%$ confidence intervals of the odds ratios were wide and revealed a certain lack of precision due to the size of the exposure groups after stratification. Another possibility could have led to a lack of precision also. In small industries there is no clear dividing line between exposure and nonexposure. Thus certain subjects with indirect or low levels of exposure may have been included in the nonexposure group (misclassification error). The results on the role of precipitins as an exposure indicator concur with those of other authors (44-46).

The pulmonary function analyses showed the adjusted $\mathrm{FEV}_{1,0}$ and $\mathrm{FEF}_{25-75}$ means for the subjects exposed to conidia to be significantly lower than those of the unexposed subjects (table 5). Similar results were reported for farmers by Heller et al (47) and Dosman et al (48). A lack of correlation between the spirometric parameters and the length of exposure to conidia may have been due in part to worker turnover, the immunologic nature of hypersensitivity pneumonitis, and a possible tolerance phenomenon in some of the affected subjects (49).

For the workers exposed to cork dust, the ANCOVA found only the mean of the adjusted $\mathrm{FEF}_{25-75}$ to be significantly lower than that of the unexposed subjects. On the other hand, the multiple regression (table 6) showed a significant decrease in the spirometric values with length of exposure in that group of workers. This effect may have been due to the airborne character of cork dust $(3,4)$, and it may point to a dose-response relation. The specificity and significance of this finding, and the increased risk for chronic bronchitis among the workers exposed to cork dust, support the plausibility of an airflow obstruction effect.

We failed to detect any pulmonary function impairment in the TDI-exposed workers. However, this finding may have been due to a selection bias caused either by the high worker turnover or the risk for asthma observed in this group, and by the fact that asthmatic patients have symptom-free periods with normal lung function.

The fact that smoking had a significant airflow limitation effect on pulmonary function in the study population does not explain the aforementioned results with respect to spirometric impairment, which can be attributed to job exposures and inherent risk factors.
Given the plausibility of these associations, follow-up will be necessary.

In summary, exposure to cork dust, TDI, and conidia in cork processing may give rise to symptoms of respiratory disease. Specific exposure-response relationships per exposure category suggest that suberosis is comprised of several different diseases, ie, asthma, chronic bronchitis, and hypersensitivity pneumonitis. Thus, all surveys on suberosis should take into account these factors and diseases. Similarly, surveys on occupational health hazards should consider the fact that the disease under study could be a compound of diverse syndromes caused respectively by different determinants involved in the manufacturing process.

\section{Acknowledgments}

The authors wish to thank Dr JM Anto for his critical review of the manuscript and helpful suggestions, Professor A Reggiani and Dr P Comba for their advice on the study design, Dr V Zunzunegui for her advice on the statistical analysis, Dr MJ Rodrigo and Ms C Sala for their advice on the precipitin test, and $\mathrm{Mr}$ F Burgos for his spirometer calibrations. We would also like to thank Ms I Alegre, Ms M Banque, Mr A Marco, Ms V Conde, Mr X Masia, and the technical staff of the Gabinete de Seguridad e Higiene en el Trabajo, Gerona, for the data collection and Ms C O'Hara for her help with the English version of this paper.

\section{References}

1. Avila R, Villar TG. Suberosis: respiratory disease in cork workers. Lancet 1968;1:620-1.

2. Cortez Pimentei J, Avila R. Respiratory disease in cork workers (suberosis). Thorax 1973;28(4):409-23.

3. Avila R, Lacey J. The role of Penicillium frequentans in suberosis. Clin Allergy 1974;4:109-17.

4. Lacey $\mathbf{J}$. The air spora of a Portuguese cork factory. Ann Occup Hyg 1973;16:223-30.

5. Brugsch $\mathbf{H}$, Elkins $\mathrm{H}$. Toluene diisocyanate (TDI) toxicity. N Engl J Med 1963;268:353-7.

6. Peters M, Murphy R. Pulmonary toxicity to isocyanates. Ann Intern Med 1970;73:654-5.

7. Wegman D. A dose response relationship in TDI workers. J Occup Med 1974;16:258-60.

8. Wegman D, Peters J, Agnotto P, Fine J. Chronic pulmonary function loss from exposure to toluene diisocyanate. $\mathrm{Br} \mathrm{J}$ Ind Med 1977;34:196-200.

9. Butcher B, Jones R, O'Neil C, et al. Longitudinal study of workers employed in the manufacture of toluene diisocyanate. Am Rev Respir Dis 1977;116:411-21.

10. Butcher B, Karr R, O'Neil C, et al. Inhalation challenge and pharmacologic studies of toluene diisocyanate (TDI) sensitive workers. J Allergy Clin Immunol 1979;64: $146-52$.

11. Diem J, Jones R, Hendrick J, et al. Five-year longitudinal study of workers employed in a new toluene diisocyanate manufacturing plant. Am Rev Respir Dis 1982;126:420-8.

12. Gamble J, Spirtas R. Job classification and utilization of complete work in occupational epidemiology. J Occup Med 1976;18:399-404. 
13. Ferris B. Epidemiology standardization project. Am Rev Respir Dis 1978;118:1-120.

14. The Occupational and Environmental Health Committee of the American Lung Association of San Diego and Imperial Counties. Taking the occupational history. Ann Intern Med 1983;99:641-51.

15. Grant I, Blyth W, Wardrop V, et al. Prevalence of Farmer's lung in Scotland: a pilot survey. Br Med J $1972 ; 1: 530-4$

16. Medical Research Council. Definition and classification of chronic bronchitis for clinical and epidemiological purposes: a report to the Medical Research Council by their committee on the aetiology of chronic bronchitis. Lancet 1965;1:775-9.

17. Dodge $R$, Burrows $B$. The prevalence of asthma and asthma-like symptoms in a general population sample. Am Rev Respir Dis 1980;122:567-75.

18. Enarson D, Vedal S, Schulzer M, Dybuncio A, Chanyeung $\mathrm{M}$. Asthma, asthma-like symptoms, chronic bronchitis, and the degree of bronchial hyperresponsiveness in epidemiologic surveys. Am Rev Respir Dis 1987; 136:613-7.

19. American Thoracic Society. ATS statement - Snowbird workshop on standardization of spirometry. Am Rev Respir Dis 1979;119:831-8.

20. Petusevsky M, Lyons L, Smith A, Epler G, Gaensler E. Calibration of time derivatives of forced vital capacity by explosive decompression. Am Rev Respir Dis 1980; $121: 343-50$.

21. Weiss N, Liff J. Accounting for the multicausal nature of disease in the design and analysis of epidemiologic studies. Am J Epidemiol 1983;117:14-7.

22. Anderson D, Mantel N. Reviews and commentary on epidemiologic surveys. Am J Epidemiol 1983;118: $613-9$.

23. Bishop YMH, Fienberg SE, Holland PW. Discrete multivariate analysis: theory and practice. Cambridge, MA: MIT Press, 1975.

24. Brown MB. Identification of the sources of significance in two-way contingency tables. Appl Stat 1974;23: 405-13.

25. Enterline PH. Pitfalls in epidemiological research. J Occup Med 1976;18:150-6.

26. Tockman M. Epidemiology in the workplace: the problem of misclassification. J Occup Med 1982;24:21-4.

27. Mur J-M, Cavelier CL. Significance of cross-sectional surveys in occupational epidemiology. Scand J Work Environ Health 1982;8(suppl 1):24-5.

28. Fletcher $\mathrm{CH}$, Peto $\mathrm{R}$. The natural history of chronic airflow obstruction. Br Med J 1977;1:1645-8.

29. Lebowitz MD. Smoking habits and changes in smoking habits as they relate to chronic conditions and respiratory symptoms. Am J Epidemiol 1977;105: 534-43.

30. Sharp J, Paul O, Mckean H, Best W. A longitudinal study of bronchitis symptoms and spirometry in a middle-aged, male, industrial population. Am Rev Respir Dis 1973;108:1066-77.

31. British Medical Research Council. Chronic bronchitis and occupation. Br Med J 1966;8-I:101-2.
32. Morgan WKC. Industrial bronchitis. $\mathrm{Br} \mathrm{J}$ Ind Med 1978;35: 285-91.

33. Mclaughlin AIG. Chronic Bronchitis and occupation. Br Med J 1966;1:354.

34. Rogan J, Attfield M, Jacobsen M, Rae S, Walker D, Watson W. Role of dust in the working environment in development of chronic bronchitis in British coal miners. Br J Ind Med 1973;30:217-26.

35. Dosman J, Graham B, Cotton D. Chronic bronchitis and exposure to cereal grain dust. Am Rev Respir Dis 1979;120:477-80.

36. Dosman J, Cotton D, Graham B, Robert K, Froh F, Barnett $G$. Chronic bronchitis and decreased forced expiratory flow rates in lifetime nonsmoking grain workers. Am Rev Respir Dis 1980;121:11-6.

37. Merchant JA, Kilburn KH, O'Follon WM, Hamilton JD, Lumdsen JC. Bysinosis and chronic bronchitis among cotton textile workers. Ann Intern Med 1972; 76:423-33.

38. Gandevia B. Studies of ventilatory capacity and histamine response during exposure to isocyanate vapour in polyurethane foam manufacture. Br J Ind Med 1963; 20:204-9.

39. Carrol K. Asthma due to non-occupational exposure to toluene diisocyanate. Clin Allergy 1976;6:99-104.

40. Peters IM, Wegman DH. Epidemiology and toluene diisocyanate (TDI) induced respiratory disease. Environ Health Perspect 1975;11:97-100.

41. Madsen D, Klock L, Wenzel F, Robbins J, Schmidt C. The prevalence of farmer's lung in an agricultural population. Am Rev Respir Dis 1976;113:171-4.

42. Grant I, Blackadder E, Greenberg M, Blyth W. Extrinsic allergic alveolitis in Scottish maltworkers. Br Med J 1976;1:490-3.

43. doPico G. Report on diseases. Am J Ind Med 1986; 10:261-5.

44. Cormier Y, Bélangeer J, Durand P. Factors influencing the development of serum precipitins to farmer's lung antigen in Quebec dairy farmers. Thorax 1985;40: $138-42$.

45. Fink J, Sosman A, Salvaggio J, Barboriak J. Precipitins and the diagnosis of a hypersensitivity pneumonitis. $J$ Allergy Clin Immunol 1971;48:179-81.

46. Kawai T, Salvaggio J, Arquembourg P, Marsh D. Precipitin antibodies against organic dust antigens in human sera by counterimmunoelectrophoresis. Chest 1973;64:420-5.

47. Heller R, Hayward D, Farebrother M. Lung function of farmers in England and Wales. Thorax 1986;41: $117-21$.

48. Dosman J, Graham B, Hall D, Van Loon P, Bhasin P, Froh F. Respiratory symptoms and pulmonary function in farmers. J Occup Med 1987;29:38-43.

49. Monkare S, Ikonen M, Maahtela T. Radiologic findings in farmer's lung disease: prognosis and correlation to lung function. Chest $1985 ; 87: 460-6$.

Received for publication: 13 July 1989 